\title{
Tourism Dependency and Perceived Local Tourism Governance: Perspective of Residents of Highly-Visited and Less-Visited Tourist Destinations
}

\author{
Jelena Đurkin Badurina *(D) and Daniela Soldić Frleta (D) \\ Faculty of Tourism and Hospitality Management, University of Rijeka, 51000 Rijeka, Croatia; danielas@fthm.hr \\ * Correspondence: jelenad@fthm.hr
}

Citation: Đurkin Badurina, J.;

Soldić Frleta, D. Tourism Dependency

and Perceived Local Tourism

Governance: Perspective of Residents of Highly-Visited and Less-Visited

Tourist Destinations. Societies 2021, 11,

79. https://doi.org/10.3390/

soc11030079

Academic Editor: Ieva Stončikaitè

Received: 30 May 2021

Accepted: 8 July 2021

Published: 13 July 2021

Publisher's Note: MDPI stays neutral with regard to jurisdictional claims in published maps and institutional affiliations.

Copyright: (c) 2021 by the authors. Licensee MDPI, Basel, Switzerland. This article is an open access article distributed under the terms and conditions of the Creative Commons Attribution (CC BY) license (https:// creativecommons.org/licenses/by/ $4.0 /)$.

\begin{abstract}
In light of the challenges of the global pandemic caused by COVID-19, the topic of overtourism has been temporarily pushed into the background, but unsustainable tourism practices, which often include ignoring residents, one of the key stakeholders in tourist destinations, remain an important issue for sustainable tourism development in the future. This is a particularly important task for local tourism governances in terms of developing mechanisms for involving residents in planning and decision making. This research focuses on gaining insights into the relationship between the tourism dependency of residents and their perception of local tourism governance in terms of satisfaction with the organization of local public and private tourism stakeholders, as well as with the involvement of residents in tourism planning and decision making. The added value of the research lies in comparing the attitudes of residents in a highly-visited destination and a destination in the early stage of development. Both selected destinations are seaside destinations. with prevailing private accommodation and residential type of tourism. Responses were analyzed using ANOVA and the t-test, and the obtained results indicate that residents with no connection to tourism are the most dissatisfied with the local tourism governance dimensions. Also, residents who live in highly-visited destination had lower mean values of perceived local tourism governance than those living in less-visited destination.
\end{abstract}

Keywords: residents; tourism dependency; local tourism governance; overtourism

\section{Introduction}

Global phenomena such as migrations as well as threats like terrorism, military conflicts, and pandemics all have huge potential to seriously impact the tourism industry and completely change the path of future tourism development. This is particularly visible in the case of the COVID-19 pandemic, which has tremendously affected national economies worldwide, especially tourism systems [1]. Before the coronavirus emerged, much attention had been given to overtourism issues, in terms of addressing the "excessive growth of visitors leading to overcrowding in areas where residents suffer the consequences of temporary and seasonal tourism peaks" [2]. In 2021, the current situation in the tourism sector is focused on creating and implementing a system of public health measures efficient enough to prevent the infection rate from growing, yet flexible enough to enable basic tourism-related activities. While it is quite certain that tourists have (temporarily or even permanently) changed their attitudes, motivations, and decision-making process for choosing a particular tourist destination, due to health crises-related factors [3], it is also probable that residents of tourist destinations might have somewhat different viewpoints on the benefits and costs that tourism activities bring to their communities [4]. Therefore, even greater responsibility will now be upon local tourism governance systems in delivering measures and actions to ensure the safety of tourists visiting a destination, but also to protect local residents from potentially increased infection rates. Previous studies confirmed that the powerful stakeholders are important partners of governance, however, 
little attention was given to the role of local residents [5]. At the same time, the residents' attitudes towards local tourism governance and the quality of organization of private and public tourism stakeholders within the destination should receive additional attention.

As important stakeholders in tourism development, local residents' perception of tourism impacts (positive and negative) and their support for tourism development is a topic explored in a large number of studies (see more in [6]). The most common framework used is the social exchange theory, stating that individuals' attitudes towards tourism and their subsequent level of support for its development will be influenced by their evaluations of the outcomes of tourism for themselves and their communities [7]. More recent lines of research also include residents' well-being and quality of life as important dimensions related to perceived tourism impacts [7-10].

One of the potential predictors of residents' positive attitudes towards tourism is economic reliance on tourism activities [11,12]. As an intrinsic factor, economic reliance on tourism (also known as tourism dependency or economic dependency) was generally used to determine whether the local residents' income or employment relies on tourism-related activities [13]. Tourism dependency has been considered as positively correlated to support for tourism development [14], and the more the residents are dependent on tourism-based income, the more they will recognize benefits from tourism, and exhibit positive attitudes towards further tourism development while being less disapproving of the negative effects of tourism $[15,16]$. Also, it was proven that economic dependency has a moderating effect on the residents' support for sport tourism development [17] and gaming development [18]. Some studies, however, such as that of Teye and associates [19], challenge the prevailing hypothesis of "higher tourism-dependency-more positive attitudes and support for tourism" as their research, conducted in Ghana, revealed that inhabitants working in tourism-related activities actually had more negative attitudes towards the sector.

While the link between tourism dependency, perceived positive and negative tourism impacts, and overall tourism support has been investigated, there is no research (at least to the knowledge of the authors) on the influence of tourism dependency on residents' perceptions of the quality of local tourism governance. Local tourism governance is hard to unanimously define but can be perceived in terms of various forms of organizing among private, public, and voluntary sector stakeholders in a tourism destination for the purpose of developing and managing tourism [20]. Although some authors in their work consider local tourism governance solely consisting of public sector institutions/decision-makers who are steering the tourism development (as visible in Presenza [21]), it is important to extend the scope of tourism governance stakeholders also on private sector stakeholders through various form of public-private partnerships, networks, and community approach, which involves also local residents [22]. Moreover, Coutinho and associates argue [23] that tourism governance faces three types of organizational challenges: involvement of each stakeholder within the network, defined by their empowerment and level of interest in a given issue; each stakeholder's understanding of their role and the role of others within the network; and the consensus and representative power of each person within the network, thereby avoiding personal interests within the network [23], p. 66. Their framework of tourism governance encompasses interdependence, relationships, and cooperation among private, public, and third sector stakeholders, operationalized through various types of governance networks. The role of trust, power, and social capital should be examined in exploration of governance networks and evaluation of their sustainability [24].

Efficient, transparent, and participatory local tourism governance should envisage mechanisms for the active involvement of residents in tourism-related decision-making at the local level [23]. The engagement of local residents in the decision-making process related to tourism development is important for their being informed on tourism development $[7,25]$ and for the fair and equitable distribution of social and economic benefits among the community members [26]. As stated by Wesley and Ainsworth, resident engagement in decision making in local communities can produce desirable results when that engagement is meaningful and participants in the process believe their input is valu- 
able [27]. However, a precondition for active engagement is positive perception of the particular topic/activity and trust in local governance mechanisms.

Residents' attitudes towards local tourism governance as well as the involvement of residents in decision making require more attention in tourism destinations with a significant share of holiday homes and private accommodation facilities (usually owned and managed by locals), as opposed to commercial destinations with predominant hotel accommodation. The reason for such emphasis lies in the somewhat different power relations among tourism stakeholders in destinations with the absence of big hotel companies as carriers of the accommodation sector. Another important element to be considered in exploring potential differences in the perception of local governance and resident's involvement is definitely the level of development and visitation of a particular tourist destination. Having in mind the evidence from various examples of the overtourism phenomenon, it is to be expected that residents living in highly-visited tourist destinations will be more irritated by tourism activities and will also blame local private and public tourism stakeholders and their governance systems for the emerging problems [28,29].

In the context of the above-mentioned, the following two research questions are derived:

- Do residents who are more economically dependent on tourism perceive local tourism governance differently than those whose incomes do not directly depend on tourism development?

- Do residents of highly-visited (mature) tourist destinations perceive the quality of local tourism governance and the level of involvement of residents in decision making differently than the residents of less-visited destinations?

In order to answer the research questions and provide insights related to the analyzed concepts, the authors conducted a survey (online and onsite) among residents of two selected tourist destinations in Croatia. Two coastal destinations were selected: one mature destination and one at the early stage of tourism development. Responses were analyzed using quantitative methods (ANOVA). The obtained results are interpreted in the light of potential contribution to academia, but also to decision-makers at the local tourism level. Relevance of the presented results can also be viewed in the light of better understanding the influence of tourism dependency on residents' attitudes in times when tourism is extremely volatile and is hard to expect it to drive the entire economy of countries.

\section{Materials and Methods}

\subsection{Study Setting}

Croatia is a country heavily dependent on tourism activities, with tourism accounting for nearly $20 \%$ of its total GDP. Although it comprises tourist destinations of different profiles offering various experiences, the most prominent Croatian tourism product is still coastal tourism, accompanied by high seasonality. For the purpose of this study, two small coastal destinations were selected. One of them (Vir) is a very popular, mature island destination focused on seaside residential tourism, while the other (Ližnjan) is still rather unspoiled by heavy tourism development. The characteristics of both destinations are presented in Table 1.

Table 1. Comparison of number of inhabitants and number of visitors of Vir and Ližnjan.

\begin{tabular}{ccc}
\hline & $\begin{array}{c}\text { Number of Inhabitants } \\
\text { (According to 2011 Census) }\end{array}$ & Number of Visitors in 2019 [30] \\
\hline Vir & 3000 & 95,413 \\
\hline Ližnjan & 3965 & 32,611 \\
\hline
\end{tabular}

As can be seen in Table 1, the chosen destinations are very different in terms of popularity, demonstrated by the number of visitors, even though they share similar accommodation structures and both are focused on the sun and sea tourism product. 
Figure 1 shows the map of Croatia and position of Vir and Ližnjan.

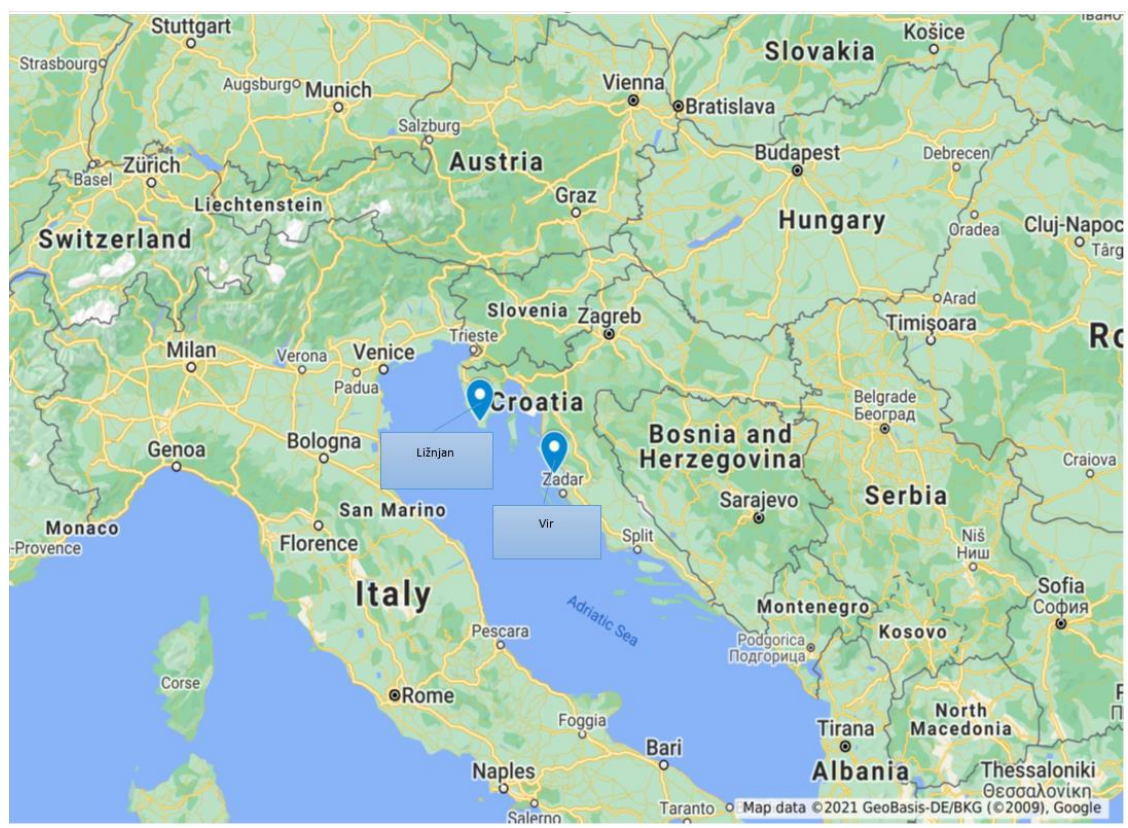

Figure 1. Map of Croatia and position of Vir and Ližnjan (adapted from Google maps).

The island of Vir is located in coastal region of Dalmatia in Croatia and has a $31.43 \mathrm{~km}$ long coast-line [31]. Today tourism is the main economic activity on the island, and its accommodation structure is comprised exclusively from renting rooms and apartments (private accommodation) without hotels. It is known as the destination of residential tourism with around 7000 holiday homes and numerous apartments [10]. The majority of tourists on Vir are foreign (86.3\%) and, just like many other small Adriatic destinations, Vir faces heavy seasonality issues since most tourism activities take place only during summer season-more than $83 \%$ of total arrivals register in July and August [30]. Having in mind that the island has only around 3032 inhabitants [31] and according to Croatian Bureau of Statistics [30] it is visited by over 90,000 tourists responsible for over 700,000 overnights during the year (in pre-COVID years), it is easy to assume that during summer, life on the island changes drastically.

On the other hand, Municipality of Ližnjan is small coastal community in the region of Istria in Croatia, situated in the immediate vicinity of bigger and more prominent tourist destinations of Pula and Medulin. Its accommodation structure is also completely oriented on private accommodation (without hotel type of accommodation) and seasonally oriented, but with much lower numbers of available beds and visitors per year-e.g., in 2019 Ližnjan was visited by 32,611 tourists with 248,006 overnights in total [30].

\subsection{Methods}

The questionnaire used in this study was developed as a part of a larger study related to overtourism and its potential effects. The original questionnaire adopted items from previous studies and included several parts that measured the residents' perceived impacts of tourism and their level of tourism support, and gathered the respondents' attitudes towards the tourism governance and their sociodemographic and economic information. For the purpose of this paper, variables related to tourism governance were used for comparison between destinations. Local tourism governance was operationalized through three statements:

- "I am satisfied with the quality of the local private-sector stakeholders' organization" (variable: private sector organization); 
- "I am satisfied with the quality of local public-sector stakeholders' organization" (variable: public sector organization);

- "I am satisfied with the level of involvement of local residents in tourism-related planning and decision making" (variable: involvement of residents).

Tourism dependency as a potential predictor of the perception of local tourism governance was operationalized through the following options: "permanent employment in tourism" ("permanent"), "seasonal employment in tourism" ("seasonal"), "additional income coming from tourism (e.g., private accommodation owner)" ("additional income") and "no connection to tourism at all" ("no connection"). Descriptive statistics were used to analyze the demographic characteristics of the research sample, and mean values were calculated in order to illustrate and compare the researched variables. Having in mind research questions focusing on comparison of perceptions and the four level of tourism dependency defined in the questionnaire (categorical variables), analysis of variance (ANOVA) was chosen as a statistical method. It is a special case of a regression model with categorical predictors, and suitable for the purpose and dataset characteristics of this research (more on characteristics of ANOVA and key assumptions to be met in Troncoso and associates [32]). Analysis of variance (ANOVA) was used to determine potential statistically significant differences based on tourism dependency, together with the Tukey/Games Howell post hoc test. The independent samples t-test was used to test the existence of potentially statistically significant differences in perceptions based on the place of residence (Vir or Ližnjan). Analysis was conducted using the statistical package IBM SPSS Statistics 23.0.

The survey was conducted in 2019. Onsite surveying of residents was performed by trained research assistants who contacted potential respondents. They randomly selected the households and those were not revisited. If they could not secure an interview at a given household (due to refusals, ineligibility, or no one at home), they moved on to the next household. As for the online survey, a link to the online questionnaire was shared among potential participants through social networks as well as the official websites of local tourist boards in the chosen destinations.

\subsection{Sample}

In total, 414 valid questionnaires were collected: 265 in Vir and 149 in Ližnjan. In the Table 2 are presented most important demographic characteristics of the respondents.

Table 2. Demographic profile of respondents.

\begin{tabular}{ccccc}
\hline & \multicolumn{2}{c}{ Vir $(n=265)$} & \multicolumn{2}{c}{ Ližnjan $(n=149)$} \\
\hline & $n$ & $\%$ & $n$ & \\
\hline Male & 126 & Gender & 61 & 40.9 \\
\hline Female & 128 & 51.3 & 84 & 56.4 \\
\hline Missing & 1 & 48.3 & 4 & 2.7 \\
\hline & & 0.4 & 3 & 2.0 \\
\hline $18-25$ & 39 & Age & 23 & 30.4 \\
\hline $26-35$ & 70 & 14.7 & 46 & 26.2 \\
\hline $36-45$ & 51 & 26.4 & 39 & 25.5 \\
\hline $46-55$ & 52 & 19.2 & 38 &
\end{tabular}


Table 2. Cont.

\begin{tabular}{|c|c|c|c|c|}
\hline & \multicolumn{2}{|c|}{$\operatorname{Vir}(n=265)$} & \multicolumn{2}{|c|}{ Ližnjan ( $n=149)$} \\
\hline & $n$ & $\%$ & $n$ & $\%$ \\
\hline \multicolumn{5}{|c|}{ Education } \\
\hline $\begin{array}{c}\text { Elementary } \\
\text { school }\end{array}$ & 18 & 6.8 & 3 & 2.0 \\
\hline High school & 155 & 58.5 & 55 & 36.9 \\
\hline College & 81 & 30.6 & 69 & 46.3 \\
\hline Master/PhD & 10 & 3.8 & 18 & 12.1 \\
\hline Missing & 1 & 0.4 & 4 & 2.7 \\
\hline \multicolumn{5}{|c|}{ Connection to tourism } \\
\hline $\begin{array}{l}\text { Permanent work } \\
\text { in tourism }\end{array}$ & 61 & 23.0 & 10 & 6.7 \\
\hline $\begin{array}{c}\text { Seasonal } \\
\text { employment in } \\
\text { tourism }\end{array}$ & 33 & 12.5 & 9 & 6.0 \\
\hline $\begin{array}{l}\text { Tourism as } \\
\text { additional } \\
\text { source of income } \\
\text { (private } \\
\text { accommodation } \\
\text { owners) }\end{array}$ & 53 & 20.0 & 74 & 49.7 \\
\hline $\begin{array}{l}\text { No relation to } \\
\text { tourism }\end{array}$ & 118 & 44.5 & 56 & 37.6 \\
\hline
\end{tabular}

Table 2 summarizes demographic and resident characteristics across the two selected destinations. It is visible that among respondents from Ližnjan there are very few of those permanently working in tourism, and respondents from Ližnjan exhibit higher level of obtained education than those from Vir.

\section{Results}

The presentation of results starts with analysis of potential statistically significant differences between respondents (based on their tourism dependency level), when it comes to perceptions of local tourism governance.

From the Table 3 it is obvious that residents do not perceive particularly highly either dimension of local tourism governance. The dimension with the lowest score per category of connection to tourism is oriented to the involvement of residents, while the category with the overall lowest scores consists of residents without any connection to tourism. It remains to be discussed whether the reason for such low scores related to residents with no connection to tourism lies in their lack of knowledge/experience with the authorities and actual extent of power of local public and private organizations in terms of dealing with tourism-related issues, or perhaps they feel most affected by negative impact of tourism, while not having any direct benefit from it. Almost extreme dissatisfaction with the involvement of residents (overall mean for all respondents is 2.33) represents an important "red flag" for local tourism stakeholders as well as tourism decision-makers. 
Table 3. Results of ANOVA for tourism dependency as independent variable and perceived local tourism governance as dependent variable.

\begin{tabular}{|c|c|c|c|c|c|c|c|c|c|c|}
\hline & \multicolumn{2}{|c|}{$\begin{array}{l}\text { Permanent Work } \\
\text { in Tourism }\end{array}$} & \multicolumn{2}{|c|}{$\begin{array}{c}\text { Seasonal } \\
\text { Employment in } \\
\text { Tourism }\end{array}$} & \multicolumn{2}{|c|}{$\begin{array}{c}\text { Tourism as Additional } \\
\text { Source of Income (Private } \\
\text { Accommodation Owners) }\end{array}$} & \multicolumn{2}{|c|}{$\begin{array}{l}\text { No Relation to } \\
\text { Tourism }\end{array}$} & \multirow[t]{2}{*}{$\mathbf{F}$} & \multirow[t]{2}{*}{$p$} \\
\hline & Mean & $\begin{array}{c}\text { St. } \\
\text { Dev. }\end{array}$ & Mean & $\begin{array}{c}\text { St. } \\
\text { Dev. }\end{array}$ & Mean & St. Dev. & Mean & St. Dev. & & \\
\hline $\begin{array}{l}\text { Private sector } \\
\text { organization }\end{array}$ & 3.29 & 1.175 & 2.55 & 1.216 & 3.20 & 1.305 & 2.34 & 1.196 & 15,309 & 0.000 \\
\hline $\begin{array}{l}\text { Public sector } \\
\text { organization }\end{array}$ & 3.26 & 1.432 & 2.51 & 1.330 & 2.90 & 1.314 & 2.13 & 1.192 & 13,663 & 0.000 \\
\hline $\begin{array}{l}\text { Involvement of } \\
\text { residents }\end{array}$ & 2.93 & 1.295 & 2.30 & 1.281 & 2.42 & 1.306 & 1.74 & 1.046 & 15,115 & 0.000 \\
\hline
\end{tabular}

Results presented in Table 3 confirm the existence of statistically significant differences among local residents in terms of their perception of local tourism governance, based on their tourism dependency. Post hoc test results in Table 4 present more details on the nature of the identified differences.

Table 4. Results of post hoc test.

\begin{tabular}{|c|c|c|c|c|c|}
\hline Dependent Variable & (I) & (J) & Mean Difference (I-J) & Std. Error & Sig. \\
\hline \multirow{12}{*}{$\begin{array}{l}\text { Private sector } \\
\text { organization }\end{array}$} & \multirow{3}{*}{ Seasonal } & Permanent & -0.736 * & 0.240 & 0.012 \\
\hline & & Additional income & $-0.655^{*}$ & 0.183 & 0.002 \\
\hline & & No connection & 0.204 & 0.173 & 0.641 \\
\hline & \multirow{3}{*}{ Permanent } & Seasonal & $0.736 *$ & 0.240 & 0.012 \\
\hline & & Additional income & 0.081 & 0.219 & 0.983 \\
\hline & & No connection & $0.941 *$ & 0.212 & 0.000 \\
\hline & \multirow{3}{*}{ Additional income } & Seasonal & $0.655 *$ & 0.183 & 0.002 \\
\hline & & Permanent & -0.081 & 0.219 & 0.983 \\
\hline & & No connection & $0.860 *$ & 0.144 & 0.000 \\
\hline & \multirow{3}{*}{ No connection } & Seasonal & -0.204 & 0.173 & 0.641 \\
\hline & & Permanent & $-0.941 *$ & 0.212 & 0.000 \\
\hline & & Additional income & $-0.860^{*}$ & 0.144 & 0.000 \\
\hline \multirow{12}{*}{$\begin{array}{l}\text { Public sector } \\
\text { organization }\end{array}$} & \multirow{3}{*}{ Seasonal } & Permanent & $-0.755^{*}$ & 0.249 & 0.014 \\
\hline & & Additional income & -0.391 & 0.190 & 0.168 \\
\hline & & No connection & 0.375 & 0.180 & 0.161 \\
\hline & \multirow{3}{*}{ Permanent } & Seasonal & $0.755 *$ & 0.249 & 0.014 \\
\hline & & Additional income & 0.364 & 0.228 & 0.380 \\
\hline & & No connection & $1.130 *$ & 0.220 & 0.000 \\
\hline & \multirow{3}{*}{ Additional income } & Seasonal & 0.391 & 0.190 & 0.168 \\
\hline & & Permanent & -0.364 & 0.228 & 0.380 \\
\hline & & No connection & $0.765^{*}$ & 0.149 & 0.000 \\
\hline & \multirow{3}{*}{ No connection } & Seasonal & -0.375 & 0.180 & 0.161 \\
\hline & & Permanent & $-1.130 *$ & 0.220 & 0.000 \\
\hline & & Additional income & $-0.765^{*}$ & 0.149 & 0.000 \\
\hline
\end{tabular}


Table 4. Cont.

\begin{tabular}{|c|c|c|c|c|c|}
\hline Dependent Variable & (I) & (J) & Mean Difference (I-J) & Std. Error & Sig. \\
\hline \multirow{12}{*}{ Involvement of residents } & \multirow{3}{*}{ Seasonal } & Permanent & -0.633 & 0.251 & 0.064 \\
\hline & & Additional income & -0.122 & 0.191 & 0.920 \\
\hline & & No connection & 0.554 * & 0.171 & 0.009 \\
\hline & \multirow{3}{*}{ Permanent } & Seasonal & 0.633 & 0.251 & 0.064 \\
\hline & & Additional income & 0.511 & 0.231 & 0.130 \\
\hline & & No connection & 1.187 * & 0.215 & 0.000 \\
\hline & \multirow{3}{*}{ Additional income } & Seasonal & 0.122 & 0.191 & 0.920 \\
\hline & & Permanent & -0.511 & 0.231 & 0.130 \\
\hline & & No connection & $0.676^{*}$ & 0.140 & 0.000 \\
\hline & \multirow{3}{*}{ No connection } & Seasonal & $-0.554 *$ & 0.171 & 0.009 \\
\hline & & Permanent & $-1.187^{*}$ & 0.215 & 0.000 \\
\hline & & Additional income & $-0.676^{*}$ & 0.140 & 0.000 \\
\hline
\end{tabular}

* Statistically significant at the level of 0.05 .

Since Levene's test of homogeneity of variances was violated only for the involvement of local residents in decision making, with regard to the respondents in Vir; that particular relationship was examined using the Games-Howell post hoc test, while all other results were obtained using Tukey's post hoc test. Results show that local resident with no connection to tourism exhibit a statistically significantly lower level of satisfaction with the organization of stakeholders in the public and private sector, as well as with the level of involvement of local residents in tourism decision making. They are followed by seasonal employees in tourism and among these two categories there are almost no statistically significant differences in most of the perceived dimensions of local governance. Residents earning additional income from tourism activities statistically significantly more positively perceive all dimensions of local tourism governance, comparing to those with no connection to tourism. Opinions of residents with additional income from tourism, on private sector organization are also more positive than the perceptions of seasonal employees. Finally, the group of respondents that are statistically most satisfied with all of the proposed dimensions of local tourism governance are residents that are permanently employed in tourism. Also, their opinion does not statistically significantly differ from the opinion of residents with additional income from tourism.

The following table explores the potential existence of statistically significant differences among perceptions between residents, based on their residence.

As can be seen in Table 5, there are statistically significant differences in the perception of local tourism governance between residents of Vir and Ližnjan in terms of organization of private and public sector stakeholders, but not when it comes to involvement of residents, which is also the variable with the lowest mean value in both destinations. All three variables are perceived more positively by the residents of Ližnjan than the residents of Vir. Having in mind that Vir is the destination with an enormous number of visits and overnights per resident, it can be hypothesized that this level of visitation does influence the residents' everyday life and decreases their satisfaction with local tourism governance. Since the highest mean value of all is only 3.27 (satisfaction of residents of Ližnjan with local private sector organization), management of both destinations should re-think the current local tourism governance system. 
Table 5. Results of T-test.

\begin{tabular}{cccccc}
\hline & \multicolumn{2}{c}{ Vir } & \multicolumn{2}{c}{ Ližnjan } & t \\
& Mean & SD & Mean & SD & Sig. (2-Tailed) \\
\hline Private sector organization & 2.47 & 1.252 & 3.21 & 1.233 & $\begin{array}{c}\mathrm{t}=-5.826 \\
p=0.000\end{array}$ \\
\hline Public sector organization & 2.42 & 1.385 & 2.77 & 1.220 & $\begin{array}{c}\mathrm{t}=-2.689 \\
p=0.008\end{array}$ \\
\hline Involvement of residents & 2.10 & 1.280 & 2.28 & 1.213 & $\begin{array}{c}\mathrm{t}=-1.347 \\
p=0.179\end{array}$ \\
\hline
\end{tabular}

\section{Discussion}

The choice of destinations that are similar in terms of geographical characteristics (small coastal communities) and type of accommodation offer provided (predomination of private accommodation/holiday homes), but very different when it comes to tourist saturation, makes it possible to draw interesting insights based on comparison of perceptions of their residents. Also, two destinations with same administrative governance status were chosen (both Vir and Ližnjan are municipalities), and both destinations have local tourist boards, which makes them also comparable from the perspective of similar public sector stakeholders.

In terms of drastic decline in tourism activities caused by COVID-19 pandemics, it is important to interpret the obtained results having in mind that both destinations are generally rather economically dependent on tourism and suffer from high seasonality, which makes them even more vulnerable in terms of consequences of pandemics [33].

Economic dependency in this research was revealed as an important predictor of residents' differences in perception. The fact that residents who are not connected to tourism activities (do not have direct benefit from it) had the lowest level of satisfaction with all three variables of local tourism governance underlines the identified need for developing new mechanisms of informing residents on direct and indirect benefits from tourism as well as involving them in planning and management of tourism on local level (as argued by Zhang and Cole [34]). It is also in line with an emphasis on community approach instead of hierarchical top-down tourism governance models [22]. Efforts of local tourism governance in sustainable management of tourist flows are important, but without engaged and informed local residents, aware of specific benefits (and costs) of tourism phenomena and limits that local tourism governance has in terms of overall power in decision-making, it is hard to avoid potential overtourism effects. This is especially important for destinations in a mature stage of development, as shown in this research (on the example of Vir), but also other Mediterranean destinations, e.g., Termoli in Italy [21]. The fact that residents who seasonally work in tourism have the second worst perception of local tourism governance dimensions calls for closer examination of the employment strategies in the tourism sector at the local level. Because of the high seasonality of tourism in the investigated destinations, the seasonal workers who are very busy during the several summer months, especially on front-line jobs, most likely have rather low chances for full-time employment in tourism [35]. Therefore, their low level of satisfaction with local tourism governance is in line with some research about attitudes of seasonal employees in tourism [36] and it partially supports the arguments of Teye and associates on the possibility that tourism "insiders" actually have more negative attitudes on tourism then those who are not directly related to it [19]. Still, this argument cannot be fully supported, because, in this research, those respondents who had permanent jobs in tourism, along with those having additional income from tourism-related activities were actually significantly more satisfied with overall tourism governance. However, overall mean values of their satisfaction are quite low. It confirms the rationale of the social exchange theory applied to residents' level of connection to tourism (see more in Pavlić and associates [37]), not just in terms of perceiving tourism impacts, but also for the perception of the organization of local 
tourism. Therefore, it can be argued that there is a link between bigger gains from tourism and more satisfaction with tourism-related mechanisms, not necessarily because they are high on quality, but because the respondents depend on them economically.

Another argument examined in this research was oriented on comparison of perceptions of destinations with different levels of tourism saturation. The statistically significant difference in residents' attitudes depending on the level of visitation of the destination they live in was partially confirmed. It implies that high-visited destinations such as Vir must give more attention to developing communication channels with residents in order to enable their participation in planning and management of future tourism activities and avoid potential overtourism [38]. Apart from changes in communication channels it is important to revise policy instruments to ensure sustainability of future tourism development, yet without significantly endangering sources of incomes for the large number of local residents. Calling for reforms and intention to decrease the volume of tourists for the sake of sustainability is a particularly sensitive topic in times of the global health crisis caused by the COVID-19 pandemic. Hence, some researchers like Butcher find calls for reduced and more controlled tourist flows threatening to a vital return to "business as usual" and irresponsible at the time when tourism businesses are devastated and tourism workers facing uncertainty [39]. Still, some popular coastal destinations in Croatia that were facing potential overtourism effects like Split or Dubrovnik had taken some measures to identify key problems and find ways to address them $[37,40]$. This research highlights that changes in strategic management are necessary for the destination of Vir, but also for Ližnjan, because although the residents of Ližnjan had statistically significantly more positive perception of local tourism governance than respondents from Vir, the overall means were still quite low on all dimensions. This implies potential structural problems in governing tourism on local level, which might be solved by new national tourism policies aiming at fostering networking of all types of tourism stakeholders and increasing efficiency of local mechanisms for planning, informing, and joint decision making.

\section{Conclusions}

The statistical significance of the results of the analysis as well as the overall low mean values of local tourism governance perceptions among residents confirm the importance of investigating the relationship between economic dependence and perception of local tourism governance. This relationship also needs special consideration in terms of the maturity of the investigated destination, as could be seen from the comparison between Vir and Ližnjan.

The research contribution of the results of this study lies in the proven importance of tourism dependency as a predictor of the perception of residents towards local tourism governance. This can help researchers to better understand the complexity of the underinvestigated topic of local tourism governance perception from the standpoint of local residents. Separating perception of public sector stakeholder organization from private sector stakeholder organization, as well as from the level of involvement of residents in decision-making, brings more clear insights on potential critical dimensions of local governance and therefore contributes to the body of knowledge on that topic. Previous research has often used a general variable for the measurement of tourism dependency (e.g., Are you related to tourism: Yes/No), but the segmentation of respondents based on the nature of their connection to tourism is obviously a more precise and scientifically relevant approach in designing a survey instrument. Hence, this represents the methodological contribution of this study to the existing body of knowledge on residents' attitudes.

Insights gained through this analysis also underline the fact that those residents who are part of the tourism system do not necessarily perceive it as being more much positive than do "outsiders". Results highlighted the specific position of residents who are seasonally employed in tourism as ones being more dissatisfied with local tourism governance than those employed in tourism permanently, as well as than those who have additional income from tourism activities. It implies complex power relations in 
governance networks in local tourism destinations but also underlines study limitations: insights gained from comparing two rather small destinations might be hard to generalize because of their strong contextual dependence (e.g., potentially specific political situation, individual characteristics of key representatives of private/public sector stakeholders, etc.) Therefore, similar research should be conducted on destinations from different countries, and maybe even include several destinations per each level of tourism saturation, in order to strengthen the obtained results. Also, in order to gain more informative and meaningful results related to the perception of local tourism governance, it would be very useful to employ a mixed-method approach, with emphasis on collecting qualitative data (perhaps through open questions in a survey or through focus groups) focused on the specific segments of local tourism governance and the most (un)satisfying elements from the perspective of residents. Finally, in terms of argued vulnerability of destinations due to the COVID-19 related situation, it would be very useful as an idea for future lines of research, to conduct empirical research on satisfaction of local residents with local tourism governance's response to COVID-19 crisis.

In terms of this study's contribution to practitioners and decision-makers, it raises the important question of involving local residents in tourism-related planning and management, and argues the need for continuous re-examination and upgrade of the governance mechanisms and their capacities for enabling residents to participate directly in local tourism development (in line with Coutinho and associates [23]). The fact that respondents from a highly-visited destination had a lower level of satisfaction with the local tourism governance than those living in the destination in the early stage of development puts the focus back on the need for constant monitoring tourism saturation, fostering informing and opinion-sharing among residents, understanding the effect that tourism dependency might have on their attitudes, and consequently preventing potential escalation of overtourism phenomena. While the results of this research can influence the policy makers in the process of creating more sustainable and systematic solutions to issues in local tourism governance systems, this study might also raise awareness among local residents about their economic dependency on tourism and how it affects their quality of life.

Enabling participation and involvement in tourism planning and (sustainable) management of existing and new offers for all relevant tourism stakeholders remains one of the key challenges of destination planners on all levels, and this study further underlines the importance of residents as stakeholders that should not be ignored in existing and emerging tourism initiatives and projects.

Author Contributions: Conceptualization, J.Đ.B. and D.S.F.; methodology, J.Đ.B.; software, J.Đ.B.; validation, J.Đ.B.; formal analysis, J.Đ.B. and D.S.F.; investigation, D.S.F.; resources, D.S.F.; data curation, D.S.F.; writing—original draft preparation, J.Đ.B.; writing—review and editing, D.S.F.; visualization, D.S.F.; supervision, D.S.F.; project administration, D.S.F.; funding acquisition, D.S.F. All authors have read and agreed to the published version of the manuscript.

Funding: This research was funded by University of Rijeka, grant number ZIP UNIRI 1/18.

Informed Consent Statement: Informed consent was obtained from all subjects involved in the study.

Conflicts of Interest: The authors declare no conflict of interest.

\section{References}

1. Gossling, S.; Scott, D.; Hall, C.M. Pandemics, tourism and global change: A rapid assessment of COVID-19. J. Sustain. Tour. 2021, 29, 1-20. [CrossRef]

2. Milano, C.; Cheer, J.; Novelli, M. Overtourism: Excesses, Discontents and Measures in Travel \& Tourism; CABI: Wallingford, UK, 2019.

3. Villace-Molinero, T.; Fernandez-Munoz, J.J.; Orea-Giner, A. Understanding the new post-COVID-19 risk scenario: Outlooks and challenges for a new era of tourism. Tour. Manag. 2021, 86, 104324. [CrossRef]

4. Qiu, R.T.; Park, J.; Li, S.; Song, H. Social costs of tourism during the COVID-19 pandemic. Ann. Tour. Res. 2020, 84, 102994. [CrossRef]

5. Bichler, B.F. Designing tourism governance: The role of local residents. J. Destin. Mark. Manag. 2021, 19, 100389. [CrossRef] 
6. Hadinejad, A.; Moyle, B.D.; Scott, N.; Kralj, A.; Nunkoo, R. Residents' attitudes to tourism: A review. Tour. Rev. 2019, 74, 150-165. [CrossRef]

7. Andereck, K.L.; Vogt, C.A. The Relationship between Residents' Attitudes toward Tourism and Tourism Development Options. J. Travel Res. 2000, 39, 27-36. [CrossRef]

8. Moscardo, G.; Konovalov, E.; Murphy, L.; McGehee, N. Mobilities, community well-being and sustainable tourism. J. Sustain. Tour. 2013, 21, 532-556. [CrossRef]

9. Dwyer, L. Tourism development and sustainable well-being: A Beyond GDP perspective. J. Sustain. Tour. 2020, 1-18. [CrossRef]

10. Soldić Frleta, D.; Đurkin Badurina, J. Well-Being and Residents' Tourism Support-Mature Island Destination Perspective. Zagreb Int. Rev. Econ. Bus. 2020, 23, 29-41. [CrossRef]

11. Ward, C.; Berno, T. Beyond Social Exchange Theory Attitudes Toward Tourists. Ann. Tour. Res. 2011, 38, 1556-1569. [CrossRef]

12. Lindberg, K.; Johnson, R. Modelling resident attitudes towards tourism. Ann. Tour. Res. 1997, 24, 402-424. [CrossRef]

13. Vieira, I.; Rodrigues, A.; Fernandes, D.; Pires, C. The role of local government management of tourism in fostering residents support to sustainable tourism development: Evidence from a Portuguese historic town. Int. J. Tour. Policy 2016, 6, 109-135. [CrossRef]

14. Chen, C.F.; Chen, P.C. Resident attitudes toward heritage tourism development. Tour. Geogr. 2010, 12, 525-545. [CrossRef]

15. Vargas-Sánchez, A.; Porras-Bueno, N.; de los Ángeles Plaza-Mejía, M. Explaining residents' attitudes to tourism. Is a universal model possible? Ann. Tour. Res. 2011, 38, 460-480. [CrossRef]

16. Almeida García, F.; Balbuena Vázquez, A.; Cortés Macías, R. Resident's attitudes towards the impacts of tourism. Tour. Manag. Perspect. 2015, 13, 33-40. [CrossRef]

17. Chang, M.-X.; Choong, Y.-O.; Ng, L.-P. Local residents' support for sport tourism development: The moderating effect of tourism dependency. J. Sport Tour. 2020, 24, 215-234. [CrossRef]

18. Yoo, J.J.; Zhou, J.Y.; Lu, T.Y.; Kim, T.T. The moderating effects of resident characteristics on perceived gaming impacts and gaming industry support: The Case of Macao. J. Travel Tour. Mark. 2014, 31, 229-250. [CrossRef]

19. Teye, V.; Sönmez, S.F.; Sirakaya, E. Residents' attitudes toward tourism development. Ann. Tour. Res. 2002, 29, 668-688. [CrossRef]

20. Beaumont, N.; Dredge, D. Local tourism governance: A comparison of three network approaches. J. Sustain. Tour. 2010, 18, 7-28. [CrossRef]

21. Presenza, A.; Del Chiappa, G.; Sheehan, L. Residents' engagement and local tourism governance in maturing beach destinations. Evidence from an Italian case study. J. Destin. Mark. Manag. 2013, 2, 22-30. [CrossRef]

22. Hall, C.M. A typology of governance and its implications for tourism policy analysis. J. Sustain. Tour. 2011, 19, 437-457. [CrossRef]

23. Coutinho, A.C.; Nóbrega, W.R. Governance in tourist destinations: Challenges in modern Society. Braz. J. Tour. Res. 2019, 13, 1-17.

24. Nunkoo, R. Governance and sustainable tourism: What is the role of trust, power and social capital? J. Destin. Mark. Manag. 2017, 6, 277-285. [CrossRef]

25. Đurkin, J.; Perić, M. Organising for community-based tourism: Comparing attitudes of local residents and local tourism entrepreneurs in Ravna Gora, Croatia. Local Econ. 2017, 32, 678-691. [CrossRef]

26. Soldić Frleta, D.; Đurkin Badurina, J. Factors affecting residents' support for cultural tourism development. In Proceedings of the ToSEE-Tourism in Southern and Eastern Europe Creating Innovative Tourism Experiences: The Way to Extend the Tourist Season, Opatija, Croatia, 16-18 May 2019; pp. 641-653.

27. Wesley, J.M.; Ainsworth, E.L. Creating Communities of Choice: Stakeholder Participation in Community Planning. Societies 2018, 8, 73. [CrossRef]

28. Koens, K.; Postma, A.; Papp, B. Is overtourism overused? Understanding the impact of tourism in a city context. Sustainability 2018, 10, 4384. [CrossRef]

29. Dangi, T.B.; Petrick, J.F. Augmenting the Role of Tourism Governance in Addressing Destination Justice, Ethics, and Equity for Sustainable Community-Based Tourism. Tour. Hosp. 2021, 2, 15-41.

30. CBS-Croatian Bureau of Statistics. Tourist Arrivals and Nights in 2019. Available online: http://www.dzs.hr/ (accessed on 15 April 2021).

31. Vir Tourism. Available online: https://www.virturizam.hr/en/island-vir/2021 (accessed on 31 January 2021).

32. Troncoso Skidmore, S.; Thompson, B. Bias and precision of some classical ANOVA effect sizes when assumptions are violated. Behav. Res. 2013, 45, 536-546. [CrossRef]

33. Duro, J.A.; Perez-Laborda, A.; Turrion-Prats, J.; Fernández-Fernández, M. Covid-19 and tourism vulnerability. Tour. Manag. Perspect. 2021, 38, 100819. [CrossRef]

34. Zhang, Y.; Cole, S.T.; Chancellor, C.H. Residents' preferences for involvement in tourism development and influences from individual profiles. Tour. Plan. Dev. 2013, 10, 267-284. [CrossRef]

35. Guidetti, G.; Pedrini, G.; Zamparini, L. Assessing perceived job quality among seasonal tourism workers: The case of Rimini, Italy. Tour. Econ. 2020. (online first). [CrossRef]

36. Nukhu, R.; Singh, S. Perceived Sustainability of Seasonal Employees on Destination and Work-A Study in the Tourism Industry. In Sustainable Human Resource Management; Vanka, S., Rao, M.B., Singh, S., Pulaparthi, M.R., Eds.; Springer: Singapore, 2020.

37. Pavlić, I.; Portolan, A.; Puh, B. (Un)supported current tourism development in UNESCO protected site. The case of Old City of Dubrovnik. Economies 2017, 5, 9. [CrossRef] 
38. Goodwin, H. Overtourism: Causes, Symptoms and Treatment. Available online: https://responsibletourismpartnership.org/wpcontent/uploads/2019/06/TWG16-Goodwin.pdf/ (accessed on 27 October 2019).

39. Butcher, J. The War on Tourism. Spiked Online 2020. Available online: https://www.spiked-online.com/2020/05/04/the-waron-tourism (accessed on 20 June 2021).

40. Pavlinović Mršić, S.; Čale, D. Analysis of the ETIS system of indicators for the assessment and monitoring of tourism sustainability in the city of Split, Croatia. Oeconomica Iadert. 2020, 10, 41-58. [CrossRef] 